\title{
KEPADATAN DAN POLA SEBARAN BENIH LOBSTER (PANULIRUS SPP.) BERDASARKAN TIPE HABITAT DI PERAIRAN DESA RANOOHA RAYA, KECAMATAN MORAMO, KABUPATEN KONAWE SELATAN
}

\section{The Density And Distribution Pattern Of Lobster Larvae (Panulirus Spp.) Based On The Type Habitats On The Waters Ranooha Raya Village, Moramo Sub-District, South Konawe Regency}

\author{
Chorgi Rahman Owu ${ }^{1}$, Muhammad Ramli², Halili ${ }^{3}$ \\ ${ }^{1}$ Mahasiswa Jurusan Ilmu Kelautan, \\ Fakultas Perikanan dan Ilmu Kelautan, Universitas Halu Oleo. \\ Jl. H.E.A Mokodompit Kampus Hijau Bumi Tridharma Anduonohu Kendari 93232, Telp/Fax: (0401) 3193782 \\ ${ }^{2}$ Surel: muh.ramli@gmail.com \\ ${ }^{3}$ Surel: halili_99@yahoo.com
}

\begin{abstract}
Abstrak
Benih lobster (Panulirus spp.) merupakan lobster berukuran kecil yang belum mempunyai kulit luar yang keras dan mengandung zat kapur dan pada umumnya ditemukan di daerah perairan pesisir. Penelitian ini bertujuan untuk mengetahui kepadatan dan pola sebaran benih lobster (Panulirus spp.) pada kawasan habitat sekitar mangrove dan lamun serta pengaruh parameter kualitas perairan terhadap benih lobster (Panulirus spp.). Pengambilan data dilakukan pada bulan Februari-September 2019, bertempat di Perairan Desa Ranooha Raya, Kecamatan Moramo, Kabupaten Konawe Selatan. Pengambilan data dilakukan pada 2 titik stasiun pengamatan dengan menggunakan metode deskriptif eksploratif yaitu menggunakan alat tangkap pocong (shelter) sebagai perangkap benih lobster, Hasil penelitian menunjukkan bahwa kepadatan tertinggi pada stasiun 2 minggu keempat yaitu 18,75 ind. $/ \mathrm{m}^{2}$ pada habitat lamun, sedangkan kepadatan terendah pada stasiun 1 minggu ketiga yaitu 2,019 ind. $/ \mathrm{m}^{2}$ pada habitat Mangrove dimana jenis yang ditemukan adalahbenih lobster mutiara (Panulirus ornatus) dan benih lobster pasir (Panulirus homarus). Pola sebaran bersifat seragam/merata pada kedua stasiun yaitu kurang dari 1 . Hasil pengukuran parameter kualitas perairan seperti suhu, salinitas, kecepatan arus, pH, kecerahan, dan DO di Desa Ranooha Raya masih mendukung kehidupan benih lobster.
\end{abstract}

Kata Kunci: Benih Lobster (Panulirus spp.), Kepadatan, Parameter Kualitas Perairan, Pola Sebaran

Abstract

Lobster larvae (Panulirus spp.) is a small lobster that do not have hard outer shells and contain calcium and commonly was found in coastal waters. The purpose of this study was to determine the density and distribution patterns of lobster larvae (Panulirus spp.) in mangrove and seagrass habitats and the effect of water quality parameters on lobster larvae (Panulirus spp.). Data was collected in February-September 2019 which located in the waters of Ranooha Raya Village, South Konawe. Sampling data was done in two stasions which used descriptive exploratory methods was used pocong fishing gear (shelter) as lobster larvae traps. The result showed that the highest density was found at station 2 in seagrass habitat on week 4 that was $18.75 \mathrm{ind} . / \mathrm{m}^{2}$, while the lowest density was found at station 1 in mangrove habitat on week 3 that was 2,019 ind. $/ \mathrm{m}^{2}$ where the type of lobster larvae either the highest or the lowest found was pearl lobster (Panulirus ornatus) and sand lobster (Panulirus homarus). The spread pattern is uniform both station 2 and station 1 was minus 1 . The result of measurement of waters quality parameters such as temperature, salinity, current speed, $\mathrm{pH}$, brightness, and DO in the village of Ranooha Raya still supported the life of lobster larvae.

Keywords: Lobster larvae (Panulirus spp.), Density, Water Quality Parameters, Distribution

\section{Pendahuluan}

Lobster laut (Panulirus sp.) merupakan jenis hewan invertebrata yang memiliki kulit yang keras dan tergolong dalam kelompok Arthropoda. Lobster memiliki 5 fase hidup mulai dari proses produksi sperma atau telur, kemudian fase larva, post larva, juvenil dan dewasa. Lobster yang telah bertelur menetas menjadi larva, larva mengalami beberapa kali pergantian kulit yaitu dari stadium nauplisoma, filosoma, puerulus (benih lobster) hingga mencapai stadium lobster muda (Rizki, 2015). Lobster mempunyai penyebaran yang sangat luas, terdapat dimana-mana pada substrat keras di laut tropis dan merupakan bagian penting fauna terumbu karang, dengan sifat ekologis mirip seperti kerabatnya yang hidup di daerah sub tropis (Sukamto $d k k$., 2016).

$$
\text { Benih lobster (Panulirus spp.) }
$$
merupakan lobster berukuran kecil yang 
belum mempunyai kulit luar yang keras dan mengandung zat kapur. Dimana, terjadi proses pergantian kulit beberapa kali, sehingga menjadi lobster muda atau kecil dan telah memiliki kerangka luar yang keras dan berzat kapur (Pratiwi, 2013).

Kepadatan dan pola sebaran benih lobster di suatu perairan ditentukan oleh habitat, lingkungan abiotik, biotik dan toleransi benih lobster terhadap masingmasing faktor lingkungan tersebut. Serta pengaruh faktor fisika kimia air, tipe substrat, ketersediaan makanan dan faktor biotik seperti pola siklus hidup, hubungan biotik dan penyebaran benih lobster tersebut.

Tipe habitat lobster pada umumnya terdapat pada kawasan terumbu karang, lamun dan mangrove. Habitat yang paling disukai adalah perairan dengan dasar pasir yang ditumbuhi rumput laut dan pada umumnya adalah di perairan pantai yang banyak terdapat bebatuan atau terumbu. Terumbu karang ini disamping sebagai pelindung (barrier) dari ombak, juga tempat persembuyian dari predator serta berfungsi sebagai daerah mencari makan. Paliniridae menyukai hidup pada lubang atau celah-celah batu karang maupun batu karang mati dan pada pasir berbatu karang disepanjang pantai dan teluk-teluk (Verianta $d k k ., 2016$ )

Desa Ranooha Raya merupakan salah satu daerah yang memiliki kawasan mangrove yang cukup luas, sedangkan untuk lamun dan terumbu karang sudah berkurang karena adanya aktivitas masyarakat yang bersifat negatif salah satunya yaitu menggunakan bom ikan saat melaut sehingga berdampak pada terumbu karang dan lamun.
Desa Ranooha Raya juga merupakan salah satu daerah yang perairannya terdapat benih lobster, dimana keberadaan benih lobster tersebut pada setiap musimnya cukup melimpah diantaranya jenis benih lobster mutiara, benih lobster pasir, benih lobster bambu dan benih lobster batik. Potensi benih lobster di perairan desa tersebut cukup tinggi dimana lobster ini merupakan salah satu komoditas penting perikanan yang memiliki nilai perdagangan atau nilai jual yang tinggi. Sehingga nelayan berinisiatif menangkap benih lobster dengan menggunakan alat tangkap sebagai perangkap atau media perlindungan bagi benih lobster dan dijadikan mata pencaharian bagi masyarakat desa tersebut.

Tujuan dari penelitian ini yaitu untuk mengetahui kepadatan dan pola sebaran benih lobster (Panulirus spp.) pada habitat mangrove dan lamun serta pengaruh parameter kualitas perairan terhadap benih lobster (Panulirus spp.).

\section{Bahan dan Metode}

Penelitian ini dilaksanakan pada bulan Februari-September 2019, bertempat di perairan Desa Ranooha Raya, Kecamatan Moramo, Kabupaten Konawe Selatan, Provinsi Sulawesi Tenggara. Adapun prosedur penelitian yang dilakukan meliputi survey pendahuluan, penentuan stasiun penelitian, metode pengambilan data dan pengukuran kualitas perairan. Data yang diambil yaitu kepadatan dan pola sebaran benih lobster berdasarkan tipe habitat di Perairan Desa Ranooha Raya.

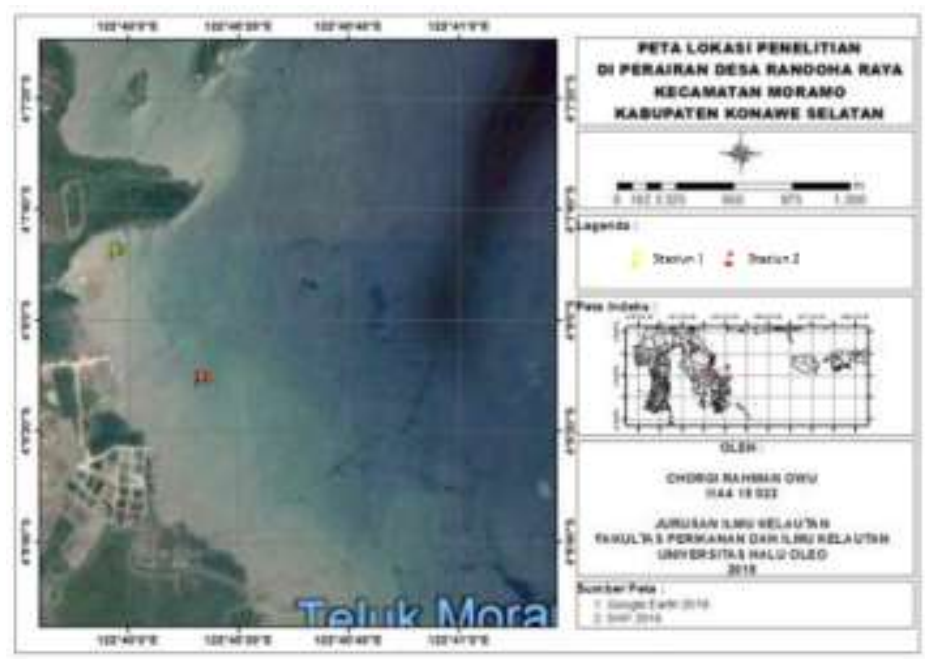

Gambar 1. Peta Lokasi Penelitian 
Berdasarkan survey pendahuluan yang telah dilakukan penentuan titik stasiun penelitian berdasarkan tipe habitat benih lobster yaitu pada kawasan habitat mangrove dan habitat lamun menggunakan metode deskriptif eksploratif yang bertujuan untuk menggambarkan keadaan yang ada, yaitu menggunakan alat tangkap pocong (shelter), dilakukan sebanyak tiga kali ulangan secara tegak lurus dari garis pantai ke arah laut.

Adapun stasiun pengambilan data dilakukan berdasarkan tipe habitat, yaitu Stasiun 1, berada pada kawasan habitat sekitar mangrove, stasiun ini berada pada pusat kordinat $4^{\circ} 7^{\prime} 50,20^{\prime \prime} \mathrm{LS}-122^{\circ} 40^{\prime} 1,76^{\prime \prime} \mathrm{BT}$. Stasiun 2, ditempatkan pada kawasan habitat lamun, stasiun ini berada pada pusat kordinat $4^{\circ} 8^{\prime} 10,14^{\prime \prime} \mathrm{LS}-122^{\circ} 40^{\prime} 14,59^{\prime \prime} \mathrm{BT}$.

Alat tangkap benih lobster atau biasa disebut pocong berfungsi sebagai shelter atau perlindungan. Alat tangkap ini terbuat dari karung semen atau karung beras yang dibentuk seperti kipas dan dipasangkan pada waring dan bagian atas diikat menyerupai pocong (Gambar 2).

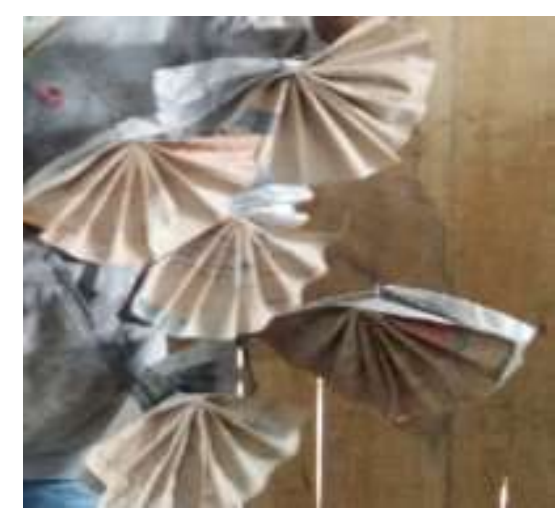

Gambar 2. Alat Tangkap Pocong (Shelter)

(Sumber: Doc. Pribadi, 2019)

Adapun prosedur pengambilan data benih lobster terdiri atas beberapa tahap, yaitu:

\section{Tahap 1. Persiapan Bahan dan Perakitan alat}

Bahan yang disiapkan untuk membuat alat tangkap pocong yaitu waring, karung semen, tali nilon, patok, tasi, pemberat (batu) dan botol (pelampung), setelah bahan terkumpul kemudian dirakit sehingga menjadi alat tangkap pocong (Gambar 2).

\section{Tahap 2. Pemasangan Alat}

Bahan yang telah dirakit segera dibawa ke perairan untuk dilakukan pemasangan.
Pemasangan dilakukan dengan cara menancapkan patok ke dasar perairan, lalu alat tangkap pocong diikat dan digantungkan pada patok agar tidak terbawa arus pada saat proses pemasangan. Pada setiap satu alat tangkap pocong memiliki panjang 50 meter dan terdapat 26 rumpon dengan jarak rumpon pertama dengan rumpon selanjutnya $1,5 \mathrm{~m}$ dengan jumlah kipas-kipas 10 lembar dalam 1 rumpon.

\section{Tahap 3. Pengambilan Sampel Benih Lobster}

Pengambilan sampel benih lobster pada setiap stasiun pengamatan dilakukan setelah dua minggu pemasangan alat tangkap. Pengambilan sampel dilakukan pada bulan Mei-Juni dengan cara mengangkat kolektor dari dalam air untuk mengumpulkan benih lobster yang menempel di sela-sela alat tangkap pocong tersebut. Pengambilan sampel untuk periode selanjutnya dengan selisih waktu kurang lebih 2 minggu. Data yang didapatkan kemudian dipisahkan dan diidentifikasi berdasarkan jenis menggunakan buku identifikasi WWF Indonesia (2015), kemudian data yang didapatkan dianalisis menggunakan perhitungan (Brower et al., 1990:81).

Parameter kualitas perairan yang diamati antara lain kedalaman, suhu, kecepatan arus, kecerahan, salinitas, dan kandungan oksigen terlarut (DO). Pengukuran kualitas perairan dilakukan secara langsung dan digambarkan secara deskriptif yaitu sebanyak 3 kali ulangan pada setiap stasiun pengamatan yang bertujuan untuk mengetahui kondisi perairan habitat benih lobster, sedangkan pengukuran nilai DO (oksigen terlarut) dilakukan dengan cara mengambil sampel air pada setiap stasiun penelitian, kemudian menganalisis di Laboratorium Perikanan dan Ilmu Kelautan.

\section{Analisis Data}

Analisis data kepadatan dan pola sebaran benih lobster dapat formulasikan dengan menggunakan rumus menurut (Brower et al., 1990:81), yaitu:

$\mathrm{Ki}=\frac{\mathrm{Ni}}{\mathrm{nA}}$

Keterangan:

$\mathrm{Ki}=$ Kepadatan pada stasiun $\mathrm{ke}-\mathrm{i}\left(\mathrm{ind} / \mathrm{m}^{2}\right)$

$\mathrm{Ni}=$ Jumlah benih pada stasiun ke-i (ind)

$\mathrm{n}=$ Jumlah unit alat tangkap

$\mathrm{A}=$ Luas penampang alat tangkap $\left(\mathrm{m}^{2}\right)$ 
Pola sebaran dihitung dengan menggunakan indeks Morisita menurut (Brower et al., 1990:81).

$i d=\frac{\mathrm{n}\left(\sum \mathrm{X}^{2}-\mathrm{N}\right)}{\mathrm{N}(\mathrm{N}-1)}$

Keterangan:

Id = Indeks Morisita

$\mathrm{n}=$ Jumlah satuan pengambilan contoh (alat tangkap)

$\mathrm{N}=$ Total jumlah individu

$\sum \mathrm{X}^{2}=$ Total dari jumlah individu dalam unit alat tangkap

Pola sebaran jenis individu dapat dikatakan seragam, acak dan mengelompok, jika:

id $<1$ : Penyebaran jenis individu bersifat seragam/merata. id $=1$ : Penyebaran jenis individu bersifat acak. id $>1$ : Penyebaran jenis individu bersifat mengelompok

\section{Hasil dan Pembahasan}

Hasil pengukuran suhu permukaan laut secara langsung di lapangan (in situ), diperoleh suhu Perairan Desa Ranooha Raya yaitu pada stasiun 1 kawasan habitat mangrove minggu ke $1-4$ berkisar $30{ }^{\circ} \mathrm{C}-31$ ${ }^{\circ} \mathrm{C}$ dan stasiun 2 habitat lamun berkisar antara
31-32 ${ }^{\circ} \mathrm{C}$. Keadaan suhu perairan yang diperoleh di kedua stasiun tersebut tidak jauh berbeda, suhu tertinggi terdapat pada stasiun 2 dengan nilai $32{ }^{\circ} \mathrm{C}$. Hal ini menunjukan bahwa nilai suhu disetiap habitat masih tergolong stabil sehingga benih lobster masih bertahan hidup dan dapat mendukung pertumbuhan benih lobster. Suhu sangat berperan mengendalikan kondisi ekosistem perairan. Suhu juga merupakan faktor penting yang sangat mendukung kehidupan biota dalam perairan seperti benih lobster. Hal ini sesuai dengan pernyataan Purnamaningtyas dan Nurfiani (2017), bahwa suhu mempengaruhi pertumbuhan juvenil spiny lobster dan spiny lobster dewasa. Lobster dapat tumbuh dengan baik pada perairan dengan suhu hangat daripada perairan dengan suhu dingin. Didukung oleh Mulya, (2012), bahwa kisaran suhu yang cenderung stabil ini tidak akan membuat lobster mengalami gangguan dalam adaptasi terhadap perubahan lingkungan sehingga menguntungkan dalam pemanfaatan energi untuk metabolisme dan pertumbuhan.

Tabel 2. Hasil Pengukuran Parameter Kualitas Perairan Minggu ke 1

\begin{tabular}{cccccccc}
\hline Stasiun & $\begin{array}{c}\text { Kedalaman } \\
(\mathbf{m})\end{array}$ & $\begin{array}{c}\text { Suhu } \\
\left({ }^{\mathbf{0}} \mathbf{C}\right)\end{array}$ & $\begin{array}{c}\text { Kecerahan } \\
(\mathbf{\%})\end{array}$ & $\begin{array}{c}\text { Kec. Arus } \\
(\mathbf{m} / \mathbf{s})\end{array}$ & $\begin{array}{c}\text { Salinitas } \\
(\mathbf{p p t})\end{array}$ & $\mathbf{p H}$ & $\begin{array}{c}\text { DO } \\
(\mathbf{m g} / \mathbf{L})\end{array}$ \\
\hline 1 & 2,00 & 31 & 73 & 0,06 & 31 & 7 & 6,2 \\
2 & 4,07 & 32 & 87 & 0,07 & 33 & 7 & 5,7 \\
\hline
\end{tabular}

Tabel 3. Hasil Pengukuran Parameter Kualitas Perairan Minggu ke 2

\begin{tabular}{cccccccc}
\hline Stasiun & $\begin{array}{c}\text { Kedalaman } \\
(\mathbf{m})\end{array}$ & $\begin{array}{c}\text { Suhu } \\
\left({ }^{\mathbf{O}} \mathbf{C}\right)\end{array}$ & $\begin{array}{c}\text { Kecerahan } \\
(\mathbf{\%})\end{array}$ & $\begin{array}{c}\text { Kec. Arus } \\
(\mathbf{m} / \mathbf{s})\end{array}$ & $\begin{array}{c}\text { Salinitas } \\
(\mathbf{p p t})\end{array}$ & $\mathbf{p H}$ & $\begin{array}{c}\text { DO } \\
(\mathbf{m g} / \mathbf{L})\end{array}$ \\
\hline 1 & 2,07 & 30 & 73 & 0,07 & 29 & 7 & 6,6 \\
2 & 4,17 & 31 & 86 & 0,08 & 31 & 7 & 4,9 \\
\hline
\end{tabular}

Tabel 4. Hasil Pengukuran Parameter Kualitas Perairan Minggu ke 3

\begin{tabular}{cccccccc}
\hline Stasiun & $\begin{array}{c}\text { Kedalaman } \\
(\mathbf{m})\end{array}$ & $\begin{array}{c}\text { Suhu } \\
\left({ }^{\mathbf{C}} \mathbf{C}\right)\end{array}$ & $\begin{array}{c}\text { Kecerahan } \\
(\mathbf{\%})\end{array}$ & $\begin{array}{c}\text { Kec. Arus } \\
(\mathbf{m} / \mathbf{s})\end{array}$ & $\begin{array}{c}\text { Salinitas } \\
(\mathbf{p p t})\end{array}$ & $\mathbf{p H}$ & $\begin{array}{c}\text { DO } \\
(\mathbf{m g} / \mathbf{L})\end{array}$ \\
\hline 1 & 2,05 & 29 & 74 & 0,07 & 29 & 7 & 6,2 \\
2 & 4,13 & 31 & 87 & 0,08 & 30 & 7 & 5,3 \\
\hline
\end{tabular}

Tabel 5. Hasil Pengukuran Parameter Kualitas Perairan Minggu ke 4

\begin{tabular}{cccccccc}
\hline Stasiun & $\begin{array}{c}\text { Kedalaman } \\
(\mathbf{m})\end{array}$ & $\begin{array}{c}\text { Suhu } \\
\left({ }^{\mathbf{C}} \mathbf{C}\right)\end{array}$ & $\begin{array}{c}\text { Kecerahan } \\
(\mathbf{\%})\end{array}$ & $\begin{array}{c}\text { Kec. Arus } \\
(\mathbf{m} / \mathbf{s})\end{array}$ & $\begin{array}{c}\text { Salinitas } \\
(\mathbf{p p t})\end{array}$ & $\mathbf{p H}$ & $\begin{array}{c}\text { DO } \\
(\mathbf{m g} / \mathbf{L})\end{array}$ \\
\hline 1 & 2,14 & 30 & 75 & 0,07 & 32 & 7 & 5,3 \\
2 & 4,20 & 31 & 86 & 0,09 & 34 & 7 & 5,7 \\
\hline
\end{tabular}


Hasil pengukuran salinitas secara langsung di lapangan (in situ) yaitu pada stasiun 1 minggu ke 1-4 berkisar antara 29-32 ppt dan stasiun 2 berkisar antara 29-34 ppt. Hal ini menunjukan bahwa nilai salinitas disetiap stasiun masih sama tergolong stabil sehingga benih lobster masih bertahan hidup dan dapat mendukung pertumbuhan benih lobster. Dimana salinitas berpengaruh terhadap pertumbuhan dan migrasi organisme laut. Hal ini sesuai dengan pernyataan Islami (2013), bahwa salinitas berpengaruh pada produksi, distribusi, lama hidup, serta migrasi biota laut.

Berdasarkan hasil pengamatan $\mathrm{pH}$ yang dilakukan secara langsung dilapangan (in situ) diperoleh nilai yaitu 7 pada setiap stasiun pengamatan, hal ini menunjukan nilai $\mathrm{pH}$ disetiap stasiun bersifat netral dan mendukung kehidupan organisme benih lobster. Hal ini sesuai dengan pernyataan Megawati $d k k$., (2014), bahwa kisaran $\mathrm{pH}$ antara 7-8 tergolong masih dianggap normal dan mendukung kehidupan organisme. Nilai $\mathrm{pH}$ yang ideal bagi perairan adalah 7-8,5. Kondisi perairan yang sangat basa maupun sangat asam akan membahayakan kelangsungan hidup organisme karena akan mengganggu proses metabolisme dan respirasi.

Berdasarkan hasil pengukuran DO yang dilakukan yaitu pada stasiun I minggu ke 1-4 berkisar antara 5,3-6,2 $\mathrm{mg} / \mathrm{L}$ dan stasiun 2 berkisar antara 4,9-5,7 mg/L. Pada setiap stasiun pengambilan data, nilai DO yang diperoleh menandakan perairan dalam kondisi sangat baik, dan masih memenuhi standar baku mutu air laut. Hal ini sesuai Keputusan Menteri Negara Lingkungan Hidup No. 51 tahun 2004 untuk kehidupan biota laut dengan nilai DO > $5 \mathrm{mg} / \mathrm{l}$, sehingga konsentrasi DO di Perairan Desa Ranooha Raya masih tergolong sesuai untuk biota laut salah satunya yaitu benih lobster. Hal ini sesuai dengan pernyataan Gemilang dkk., (2017), bahwa oksigen terlarut (DO) dibutuhkan oleh semua jasad hidup untuk pernapasan, proses metabolisme atau pertukaran zat yang kemudian menghasilkan energi untuk pertumbuhan dan pembiakan.

Tingkat kecerahan Perairan Desa Ranooha Raya pada stasiun I diperoleh 72-75 $\%$ dan stasiun 2 diperoleh $86-87 \%$. Rendahnya tingkat kecerahan pada habitat mangrove disebabkan karena banyaknya suplai sedimen dan partikel yang terlarut serta tidak terdapatnya karang dan lamun, dan didominasi oleh substrat berlumpur sedangkan pada habitat lamun kecerahannya lebih tinggi dikarenakan kurangnya suplai sedimen dan didominasi substrat berpasir. Dimana kecerahan perairan tersebut sangat berpengaruh terhadap kehidupan organisme laut. Hal ini sesuai dengan pernyataan Widiadmoko (2013), bahwa kemampuan cahaya matahari untuk menembus sampai ke dasar perairan dipengaruhi oleh kekeruhan (turbidity) air. Oleh karena itu, tingkat kecerahan dan kekeruhan air laut sangat berpengaruh pada pertumbuhan biota laut. Tingkat kecerahan air laut sangat menentukan tingkat fotosintesis biota yang ada di perairan laut.

Kecepatan arus yang telah dilakukan didapatkan nilai pada stasiun I berkisar antara $0,06-0,07 \mathrm{~m} / \mathrm{s}$ dan stasiun 2 berkisar antara 0,07-0,09 m/s. Kecepatan arus tertinggi terdapat pada stasiun 2 habitat lamun minggu ke 4 dengan nilai $0,09 \mathrm{~m} / \mathrm{s}$. Dimana. Arus ini sangat berperan penting dibadingkan parameter lainnya dikarenakan tidak ditemukan indukan lobster di Perairan Desa Ranooha Raya dan diduga keberadaan benih lobster berasal dari laut dalam dan terbawa oleh arus hingga ke perairan desa tersebut. Sehingga arus ini sangat berpengaruh dalam keberadaan benih lobster yang berada disekitar perairan desa tersebut. Hal ini sesuai dengan pernyataan Rios-Lara $d k k$., (2007), bahwa arus mempengaruhi sebaran dari larva, karena diduga benih lobster yang tersebar dan berkembang pada suatu lokasi dapat berasal dari larva yang terbawa oleh arus dari lokasi yang berbeda.

Tabel 6. Hasil Analisis Jenis Benih Lobster (Panulirus spp.)

\begin{tabular}{clccc}
\hline No. & \multicolumn{1}{c}{ Jenis Species } & $\begin{array}{c}\text { Stasiun 1 } \\
\text { (individu) }\end{array}$ & $\begin{array}{c}\text { Stasiun 2 } \\
\text { (individu) }\end{array}$ & Jumlah \\
\hline 1. & Benih lobster mutiara (P. ornatus) & 118 & 186 & 304 \\
2. & Benih lobster pasir (P. homarus) & 61 & 96 & 157 \\
\hline & Jumlah & $\mathbf{1 7 9}$ & $\mathbf{2 8 2}$ & $\mathbf{4 6 1}$ \\
\hline
\end{tabular}


Tabel 7. Hasil Analisis Kepadatan Benih Lobster (Panulirus spp.)

\begin{tabular}{|c|c|c|c|c|}
\hline \multirow[t]{2}{*}{ Stasiun } & \multicolumn{4}{|c|}{ Kepadatan Panulirus spp. (individu/m²) } \\
\hline & 1 & 2 & 3 & 4 \\
\hline I & 2,692 & 2,212 & 2,019 & 10,29 \\
\hline 2 & 3,846 & 2,115 & 2,404 & 18,75 \\
\hline
\end{tabular}

Tabel 8. Hasil Analisis Pola Sebaran Benih Lobster (Panulirus spp.)

\begin{tabular}{cccccc}
\hline \multirow{2}{*}{ Stasiun } & \multicolumn{4}{c}{ Pola Sebaran Panulirus spp. (id) } & \multirow{2}{*}{ Kriteria } \\
\cline { 2 - 5 } & $\mathbf{1}$ & $\mathbf{2}$ & $\mathbf{3}$ & $\mathbf{4}$ & \\
\hline I & 0,62 & 0,514 & 0,495 & 0,903 & seragam/merata \\
2 & 0,63 & 0,225 & 0,346 & 0,913 & seragam/merata \\
\hline
\end{tabular}

Benih lobster yang tertangkap di perairan Desa Ranooha Raya yaitu jenis benih lobster mutiara dan lobster pasir, didapatkan benih lobster dengan jumlah total 461 individu. Jumlah yang didapatkan pada stasiun 1 (kawasan habitat sekitar mangrove) sebanyak 179 individu dan pada stasiun 2 (habitat lamun) sebanyak 282 individu didominasi oleh jenis benih lobster mutiara. Dimana benih lobster tersebut diduga berasal dari laut dalam dan terbawa oleh arus hingga ke Perairan Desa Ranooha Raya, yakni indukan lobster pada setiap tahunnya akan menetaskan telurnya hingga ribuan dan menjadi benih lobster. Benih lobster bersifat planktonik sehingga pergerakannya dipengaruhi oleh arus. Hal ini sesuai dengan pernyataan Pratiwi (2013), bahwa lobster yang telah menetas di perairan laut dalam menjadi benih akan terbawa arus ke arah pantai.

Nilai kepadatan yang didapat pada setiap stasiun pengamatan yaitu pada stasiun 1 (habitat mangrove) minggu ke 1-4 berkisar antara 2,019-10,29 ind. $/ \mathrm{m}^{2}$ dan stasiun 2 (habitat lamun) berkisar antara 2,115-18,75 ind. $/ \mathrm{m}^{2}$ (Tabel 7). Dimana nilai kepadatan tertinggi terdapat pada stasiun 2 (habitat lamun) minggu ke 4 yaitu 18,75 ind. $/ \mathrm{m}^{2}$ yang terdiri dari jenis benih lobster mutiara dan lobster pasir. Tingginya kepadatan benih lobster pada habitat lamun minggu ke 4 diduga larva yang menjadi benih lobster pada minggu tersebut sudah banyak dan tersebar di Perairan Desa Ranooha Raya. Selain itu diduga adanya faktor musim yang mempengaruhi yaitu musim Timur sehingga angin dan arus lebih cenderung mengarah ke habitat lamun, dimana stasiun 2 (habitat lamun) berada di bagian Timur dan habitat mangrove berada pada bagian Barat Perairan Desa Ranooha Raya. Rendahnya kepadatan pada stasiun 1 (habitat mangrove) yang letaknya berada pada bagian Barat dipengaruhi oleh musim Timur dimana angin dan arus cenderung mengarah ke stasiun 2 . Hal ini sesuai dengan pernyataan Rios-Lara $d k k$., (2007), bahwa arus sangat berperan penting di dalam sebaran larva. Didukung oleh Philips (2006), bahwa kondisi kualitas air sangat berperan terhadap keberadaan, pertumbuhan, reproduksi, dan migrasi benih lobster di suatu perairan.

Rendahnya kepadatan benih lobster pada minggu 1-3 dikarenakan proses telur menuju fase larva membutuhkan proses yang panjang sebelum mencapai fase benih lobster yakni terdapat musim-musim tertentu untuk mencapai fase tersebut, sehingga benih lobster yang didapatkan masih kurang dikarenakan pengambilan data minggu 1-3 lebih awal dibadingkan pengambilan data minggu ke 4 . Seperti musim Utara yang terjadi pada minggu 1-3 sehingga angin dan arus cenderung menuju bagian Utara Perairan Desa Ranooha Raya. Hal ini sesuai dengan pernyataan Junaidi dkk., (2010), bahwa waktu yang ditempuh sebagai fase larva diperkirakan antara 3-7 bulan, dimana larva phyllosoma mengapung pada permukaan air dan akan terbawa oleh gelombang, arus, dan angin.

Kepadatan tertinggi dengan nilai 18,75 terdapat di stasiun 2 habitat lamun pada minggu ke 4, didapatkan hasil pengukuran parameter kualitas perairan dengan suhu 31 oC, kedalaman 4,20 m, kecerahan $86 \%$, kecepatan arus $0,09 \mathrm{~m} / \mathrm{s}$, salinitas $34 \mathrm{ppt}, \mathrm{pH}$ 7 dan DO 5,7 mg/L. Kepadatan tertinggi dari pengukuran parameter kualitas perairan pada minggu ke 4 bahwa benih lobster masih toleran dengan kondisi Perairan Desa Ranooha Raya dikarenakan keberadaan benih lobster di perairan tersebut cukup melimpah 
pada waktu tersebut serta berhubungan erat dengan kondisi dan fenomena oseanografi yang terjadi di sekitar lokasi penelitian. Hal ini sesuai dengan pernyataan Gonzalez dan Wehrtmann (2011), bahwa parameter oseanografi berhubungan erat dengan kondisi dan fenomena yang terjadi disekitar lokasi penelitian benih lobster.

Berdasarkan hasil penelitian pola sebaran benih lobster yang ditemukan di Perairan Desa Ranooha Raya secara keseluruhan bersifat merata. Pola sebaran yang merata pada benih lobster diduga disebabkan oleh adanya pengaruh musim sehingga angin dan arus cenderung mengarah ke 1 arah, banyaknya alat tangkap yang terpasang di perairan dan ketersediaan sumber makanan bagi benih lobster, sehingga keberadaan atau sebaran benih lobster berpindah kesemua lokasi atau tersebar dialat tangkap yang terpasang sehingga menjadi merata. Nilai indeks sebaran yang didapatkan pada stasiun 1 habitat mangrove yaitu berkisar antara 0,495-0,903 ind $/ \mathrm{m}^{2}$ dan stasiun 2 habitat lamun yaitu berkisar 0,206$0,913 \mathrm{ind} / \mathrm{m}^{2}$ (Tabel 8), dimana kedua habitat tersebut didapatkan indeks sebaran kurang dari 1. Hal ini sesuai dengan indeks morisita yang menyatakan bahwa jika nilai dari hasil pola sebaran organisme yang didapatkan id < 1 , maka pola penyebaran bersifat seragam atau merata. Hal ini sesuai dengan pernyataan Mahcrizal $d k k$., (2014), bahwa pola sebaran merata ini diduga disebabkan oleh karakter lingkungan dan ketersediaan makanan yang terbatas sehingga menyebabkan kompetisi antar individu dalam mendapatkan ruang yang sama.

Berdasarkan hasil penelitian pengukuran parameter kualitas Perairan Desa Ranooha Raya tidak memperlihatkan perbedaan yang mencolok disetiap stasiun. Seperti hasil pengukuran suhu permukaan yang berkisar antara $29-31{ }^{\circ} \mathrm{C}$ pada stasiun 1 dan pada stasiun II yaitu $31{ }^{\circ} \mathrm{C}$, kecepatan arus pada stasiun I berkisar antara 0,06-0,07 $\mathrm{m} / \mathrm{s}$ dan stasiun II berkisar 0,07-0,09 $\mathrm{m} / \mathrm{s}$, salinitas perairan pada stasiun I berkisar antara 29-32 ppt dan pada stasiun II berkisar antara 30-34 ppt, $\mathrm{pH}$ perairan bersifat netral yaitu 7, serta DO perairan berkisar antara 5,3$6,6 \mathrm{mg} / \mathrm{L}$ pada stasiun I dan pada stasiun II berkisar antara 4,9-5,7 $\mathrm{mg} / \mathrm{L}$. Hal ini sesuai dengan pernyataan Booth dan Kittaka (1994), bahwa suhu sangat memengaruhi pertumbuhan lobster dengan suhu optimal berkisar antara $29-30^{\circ} \mathrm{C}$. Didukung oleh Nurfaini dkk., (2016), bahwa salinitas berperan dalam proses biologi dan secara langsung terhadap laju pertumbuhan, jumlah makanan yang dikonsumsi dan daya kelangsungan hidup.

\section{Kesimpulan}

Berdasarkan hasil penelitian dapat disimpulkan bahwa:

1. Kepadatan tertinggi yaitu pada habitat lamun pada minggu keempat dengan nilai 18,75 ind. $/ \mathrm{m}^{2}$.

2. Pola sebaran benih lobster bersifat merata disetiap kawasan mangrove dan lamun yakni jenis benih lobster mutiara $(P$. ornatus) dan jenis benih lobster pasir $(P$. homarus).

3. Parameter kualitas perairan sangat berpengaruh terhadap kehidupan dan penyebaran benih lobster (Panulirus spp.) di Perairan Desa Ranooha Raya yaitu arus.

\section{Daftar Pustaka}

Brower, J. E., Zar, J. H., dan End, C.N.V. 1990. Field and Laboratory Methods For General Ecology, Third Edition. USA: Wm. C. Brown Publisher.

Gemilang, W.A., dan Kusumah, G. 2017. Status Indeks Pencemaran Perairan Kawasan Mangrove Berdasarkan Penilaian Fisika-Kimia di Pesisir Kecamatan Brebes Jawa Tengah. Enviroscienteae, 13(2), 171-180.

Gonzalez, O. dan Wehrtmann, I.S. 2011. Postlarval settlement of spiny lobster, Panulirus argus (Latreille, 1804) (Decapoda: Palinuridae), at the Caribbean coast of Costa Rica.Lat. Am. J. Aquat. Res., 39(3), 575-583.

Islami, M.M. 2013. Pengaruh Suhu dan Salinitas terhadap Bilalvia. Jurnal Oseana, Vol. 38 (2): 1-10.

Junaidi, M., Cokrowati, N. Abidin, Z. 2010. Aspek Reproduksi Lobster (Panulirus sp.) di Perairan Teluk Ekas Pulau Lombok. Jurnal Kelautan, Vol. 3 (1): 1907-9931.

Kementerian Negara Lingkungan Hidup. 2004. Keputusan Menteri Negara Lingkungan Hidup Nomor 51 Tahun 2004 tentang Baku Mutu Air Laut.

Machrizal, R., Wahyuningsih. H Dan Jumilawaty, E. 2014. Kepadatan dan 
Pola Distribusi Kijing (Glauconome Virens, Linnaeus 1767) di Ekosistem Mangrove Belawan. Jurnal Perikananan dan Kelautan ISSN: 0853-7607.

Megawati, C., Yusuf, M., dan Maslukah, L. 2014. Sebaran Kualitas Perairan Ditinjau dari Zat Hara, Oksigen Terlarut dan $\mathrm{pH}$ di Perairan Selatan Bali Bagian Selatan. Jurnal Oseanografi, Vol. 3(2): 142-150.

Mulya, M.B. 2012. Kajian Bioekologi Udang Putih (Penaeus Merguiensis de Man) di Ekosistem Mangrove Percut Sei Tuan Sumatera Utara. Skripsi. Sekolah Pasca Sarjana. Institut Pertanian Bogor. Bogor.

Nurfiarini, A., Wijaya, D., Mujiyanto, Satria, F dan Setiadi, E. K. 2016. Pendekatan Sosial-Ekologi untuk Penilaian Kesesuaian Lokasi Restocking Lobster Pasir Panulirus homarus (Linnaeus, 1758) pada Beberapa Perairan di Indonesia. Jurnal Penelitian Perikanan Indonesia, Vol. 22 (1): 123-138.

Phillips, B.F. 2006. Lobsters: Biology, Management, Aquaculture, and Fisheries. Blackwell Publishing Ltd., $506 \mathrm{pp}$.

Pratiwi, R. 2013. Lobster Komersial (Panulirus spp.) Jurnal Oseana, Vol. 38 (2): 55-68.

Purnamaningtyas, S. E dan Nurfiani, A. 2017. Kebiasaan Makan Beberapa Spiny Lobster di Teluk Gerupuk dan Teluk Bumbang. Nusa Tenggara Barat. Jurnal Akuatika Indonesia, Vol. 2 (2): 99-102.

Rios-Lara, V., Salas, S., Javier, B.P., \& IreneAyora, P. 2007. Distribution patterns of spiny lobster (Panulirus argus) at Alacranes reef, Yucatan: Spatial Analysis and Inference of Preferential Habitat. Fisheries Research, 87,35-45

Rizki,W. 2015. Perikanan Lobster laut. Panduan Penangkapan dan Penanganan. Edisi 1. Jakarta Selatan. $38 \mathrm{hlm}$.

Sukamto., Muryantodan, T. dan Kuslani, H. 2017. Teknik Identifikasi Jenis Kelamin Lobster Berbasis Ciri-ciri Morfologi. Buletin Teknik Litkayasa, Vol. 15 (2): 99-102.

Verianta, M., Zahida, F., dan Nugroho, W, J. 2016. Jenis Lobster di Pantai Baron Gunungkidul, Yogyakarta.
Widiadmoko, W. 2013. Pemantauan Kualitas Air Secara Fisika dan Kimia di Perairan Teluk Hurun. Bandar Lampung: Balai Besar Pengembangan Budidaya Laut (BBPBL) Lampung.

WWF Indonesia. 2015. Perikanan Lobster laut Panduan Penangkapan dan Penanganan, Suistainable Seafood. Jakarta Selatan. 